\title{
First study of Brucella ovis antibodies in purebred sheep flocks in the State of Parana, Brazil
}

[Primeiro estudo de anticorpos para Brucella ovis em rebanhos de ovinos puros de Origem, no estado do Paraná, Brasil]

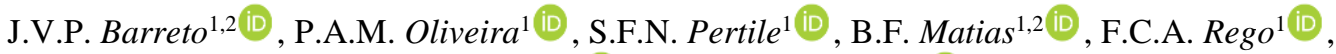 \\ T.H.C. Patelli ${ }^{3}$ (D) L.F.C. Cunha Filho ${ }^{1 \text { iD }}$ \\ ${ }^{1}$ Universidade Pitágoras Unopar, Arapongas, PR, Brasil \\ ${ }^{2}$ Graduate, Universidade Estadual de Londrina, Londrina, PR, Brasil \\ ${ }^{3}$ Universidade Estadual do Norte do Paraná, Bandeirantes, PR, Brasil
}

\begin{abstract}
Brucella ovis, a non-zoonotic species, is the etiological agent of ovine brucellosis, an infectious disease of clinical or subclinical occurrence in sheep flocks. Until then, there is no serological study of anti-Brucella ovis antibodies in purebred sheep herds. This study aimed to determine the presence of anti-Brucella ovis antibodies in purebred sheep flocks with breeding purposes from Parana State. Blood samples from 728 animals, of which 563 were females and 165 males, between 8 and 56 months of age from the six major sheep producing mesoregions of Parana, were submitted to detection of anti-Brucella ovis antibodies by the Agar Gel Immunodiffusion technique using an antigen from the bacteria Brucella ovis (Reo 198). The results indicate the presence of this disease in purebred sheep from Parana State in a low occurrence of $0.27 \%$ (2/728). The only two positive animals were rams, Santa Inês breed, from the same flock in the East Center region of Parana, without clinical disease. In conclusion, Brucella ovis is present in purebred sheep in Parana State, Brazil, and this low occurrence may have occurred due to rigorous breeding systems that may contribute to reduce the transmission of this disease.
\end{abstract}

Keyword: ovine, AGID, Brucella spp., brucellosis

\section{RESUMO}

Brucella ovis, espécie não zoonótica, é o agente etiológico da brucelose ovina, doença infecciosa de ocorrência clínica ou subclínica. Atualmente, não existe estudo sorológico de anticorpos anti-Brucella ovis em rebanhos de ovinos puros de origem. Este estudo teve como objetivo determinar a presença de anticorpos anti-Brucella ovis em rebanhos ovinos de raça pura de origem, com fins reprodutivos do estado do Paraná. Amostras de sangue de 728 animais, sendo 563 fêmeas e 165 machos, entre oito e 56 meses de idade, pertencentes a seis principais mesorregiões produtoras de ovinos no Paraná, foram submetidas à detecção de anticorpos anti-Brucella ovis pela técnica de imunodifusão em ágar gel usando-se um antígeno da bactéria Brucella ovis (Reo 198). Os resultados indicam a presença da doença em ovinos puros de origem do estado do Paraná em baixa ocorrência de 0,27\% (2/728). Os dois únicos animais positivos foram reprodutores da raça Santa Inês, do mesmo rebanho da região Centro Leste do Paraná, sem manifestação clínica. Em conclusão, Brucella ovis está presente em ovinos puros de origem no estado do Paraná, e essa baixa ocorrência pode ter ocorrido devido a sistemas rigorosos de criação, que podem contribuir para a redução da transmissão dessa doença.

Palavras-chave: ovinos, Brucella spp., brucelose, IDGA

Corresponding author: jose.proni@hotmail.com

Submitted: March 30, 2021. Accepted: August 20, 2021. 


\section{INTRODUCTION}

The ovine herds have gowned significantly worldwide (Farias et al., 2013), and Brazil, considered the $8^{\text {th }}$ world's largest sheep producer, has reached 19.715 million heads, thereby the State of Parana represents $2.98 \%$ of the Brazilian herd, totalizing 588.996 heads (Efetivo..., 2019). Despite this growth, it is important to implement awareness around risk factors, control, and prevention of brucellosis dissemination in sheep flocks (Elderbrook et al., 2019).

Brucella ovis (B. ovis), a non-zoonotic species (Poester et al., 2013), is the causative agent of ovine brucellosis, an infectious disease of clinical or subclinical occurrence (Ovine..., 2015), that is sexually transmitted and introduced into flocks by infected rams or ewes, since the etiological agent may be excreted through semen or vaginal discharge, also occurring indirectly ram-to-ram via passive venereal contact with ewes when males share the same females during the breeding season (Hartley et al., 1955; Buddle, 1955; Blasco, 2010).

B. ovis is responsible for economic and reproductive losses (Poester et al., 2013), reverberating in rams' decreased fertility, ewes' lower conception rates, and reduction in the birth of healthy lambs. Even if the most common clinical sign associated to $B$. ovis infection is epididymitis in rams, less than $50 \%$ of the infected rams develop epididymitis, revealing the possible silent character of ovine brucellosis (Van Metre et al., 2012).

The Brucella melitensis Rev. 1 vaccine is a live strain vaccine that can stimulate immunity against B. ovis, harming serological tests, but it is totally forbidden in Brazil (Ovine..., 2015). Moreover, this vaccine can cause human infection by accidental self-inoculation (Estein et al., 2009), and it is important to emphasize that there is no report of this Brucella species occurrence in Brazil.

Serological tests for antibodies detection are the most useful epidemiological tool for diagnosis of Brucella infection around the world (Erdenebaatar et al., 2004). In Brazil, the Ministry of Agriculture, Livestock and Food Supply (MAPA) recommends Agarose Gel Immunodiffusion (AGID) as the standard test
(Brazil, 2004), and it has been already used to identify seropositive sheep in the Parana State (Cunha Filho et al., 2007; Oliveira et al., 2016), but never in purebred sheep flocks.

Although the infection by $B$. ovis has already been identified in several Brazilian states using AGID as a serological diagnostic method, and it is included in the National Program for the Sanity of Goats and Sheep of Ministry of Agriculture, Livestock and Food Supply (MAPA) (Brazil, 2004), studies have demonstrated the occurrence of B. ovis antibodies only in commercial sheep herds from non-mechanized farms in Brazil through AGID test (Marinho and Mathias, 1996; Chiebao, 2011), there are even a few from Parana State (Cunha Filho et al., 2007; Oliveira et al., 2016), and most of all, there are no studies with data from purebred sheep herds that sell animals with genealogical records to properties all over the country with breeding purposes, which is of great importance since $B$. ovis is sexually transmitted (Hartley et al., 1955; Buddle, 1955; Blasco, 2010) and the infection may have silent dissemination in the flocks (Van Metre et al., 2012). Thus, this is the first serological study that aimed to determine the occurrence of antibodies anti-B. ovis in naturally infected purebred sheep from Parana State, Brazil.

\section{MATERIAL AND METHODS}

The experiment was carried out in accordance with the guidelines of the Ethics Committee on the usage of animals in experiments and was approved by the scientific committee (CEA/UNOPAR 006/16).

The minimum number of serum samples $(n=728)$ to be tested was calculated using the EpiInfo ${ }^{\circledR}$ program, using the following parameters: expected prevalence of 5\% (95\% confidence interval and $6 \%$ standard error), considering the $1.40 \%$ of prevalence observed in 2007 by Cunha Filho et al. (2007) in Parana State. The animals were randomly selected so that $10 \%$ from the total number of sheep were sampled on each farm.

Overall, this study covered farms located in the in six mesoregions of Parana State: Western Center ( $n=119$, municipality of Araruna), East Center ( $n=241$, municipalities of Castro, Piraí do Sul and Ventania), South Center $(n=49$, municipalities of Candói and Pitanga), Metropolitan Curitiba ( $n=$ 
101, municipalities of Colombo and São José dos Pinhais), North Central ( $n=185$, municipalities of Arapuã, Bom Sucesso, Itagujé, Mandaguari, Maringá and Rosário do Ivaí), and North Pioneer $(\mathrm{n}=33$, municipalities of Congoinhas and Rancho Alegre). These regions comprehend $60 \%$ of the state herd (Paraná, 2017) and are located between latitudes $22^{\circ} \mathrm{S}$ and $26^{\circ} \mathrm{S}$ (Cartas..., 2017), and and also comprised a large part of purebred sheep with genealogical registration according to information obtained through the Brazilian Association of Sheep Breeders.

The samples were collected before the breeding season, in January and February of 2017. From the total of 728 animals, ewes comprised $77.33 \%$ (563/728) and rams comprised $22.66 \%$ (165/728), between 8 to 56 months old. The animals sampled belonged to Dorper $(39.01 \%)$, Ille de France (16.62\%), Lacaune (5.22\%), Santa Ines (9.07\%), Suffolk (8.24\%), Texel (19.10), and White Dorper $(2.74 \%)$ breeds, all with genealogical records in the Brazilian Association of Sheep Breeders.

The males were all negative in the individual evaluation for the epididymitis occurrence by observation and palpation of testicular structures. The history concerning abortion, acquisition of animals and participation in fairs in the last year were fully questioned in each farm at the blood collection moment for the purpose of an epidemiological characterization. From the 728 animals, 144 (19.78\%) were kept totally confined in pens, and $584(80.22 \%)$ were kept semiconfined in pens with access to collective paddocks, but all of them had exclusively natural breeding season.

The samples were collected by jugular venipuncture and serum were separated by centrifugation and stored in sterile microtubes at $20^{\circ} \mathrm{C}$ until further analyses. Serum samples were tested by the AGID technique with sensitivity and specificity of $70 \%$ and $100 \%$, respectively (Xavier et al., 2011), at the UNOPAR Laboratory of Infectious Diseases, using the diagnostic kit produced by the Parana Technology Institute (TECPAR, Curitiba, Brazil). The antigen consists of soluble proteins and lipopolysaccharides, extracted from the bacterium Brucella. ovis, sample Reo 198.

The agar preparation was carried out according to the manufacturer's specifications. Four samples were evaluated in each petri plate $(55 \times 15 \mathrm{~mm})$, where the positive control serum was applied in the center of the plate. Plates were read $72 \mathrm{~h}$ after sample application, and samples were considered positive when a clear line of precipitation was observed between the sample and the positive control.

The data obtained for AGID test of ovine brucellosis allowed only descriptive statistics analysis and the low occurrence obtained did not allow the study of risk factors associated to $B$. ovis infection.

\section{RESULTS}

From the 728 serum samples tested, only two $(0.27 \%)$ reacted positively in the AGID test antiBrucella ovis. The only two positive animals were rams without epididymitis, Santa Inês breed, at 12 and 24 months of age, from the same flock in Ventania municipality, belonging to the East Center region of Parana, the largest region in number of sheep analyzed, representing $33.10 \%$ of the sampled animals in this study.

Although the seroreactivity results did not allow to study the risk factors associated with $B$. ovis infection in the present study, the epidemiological characterization of the animals is presented in Table 1 .

Table 1. Epidemiological characterization of the animals studied according to the occurrence of abortion, acquisition of animals and participation in fairs

\begin{tabular}{lcc}
\hline Variable & Number & $\begin{array}{c}\text { Percentage } \\
(\%)\end{array}$ \\
\hline Abortion history & 668 & 91.76 \\
Yes & 60 & 8.24 \\
No & & \\
Animal acquisition & 617 & 84.75 \\
Yes & 111 & 15.25 \\
No & & \\
Participation in fairs & 679 & 93.27 \\
Yes & 49 & 6.73 \\
No & & \\
\hline
\end{tabular}

\section{DISCUSSION}

In Brazil, the flock seroprevalence of B. ovis in the studied populations was between 0\% (Marinho and Mathias, 1996; Chiebao, 2011) and 34\% (Silva et al., 2003). Our study seroprevalence 
estimate, based on serologic testing, is much lower than other prevalence estimates published in Brazil with commercial non-mechanized sheep flocks (Magalhães Neto and Gil-Turnes, 1996; Schafer et al., 1997; Coleto et al., 2003; Silva et al., 2003; Pinheiro Junior et al., 2009; Rizzo et al., 2009; Silva et al., 2009; Alves et al., 2010; Souza et al., 2012; Araujo et al., 2013; Martins et al., 2013; Azevedo et al., 2014; Rizzo et al., 2014; Manhezzo et al., 2015; Lima et al., 2020; Teixeira et al., 2021), including 1.40\% (Cunha Filho et al., 2007 ) and $18.26 \%$ of AGID seropositive sheep (Oliveira et al., 2016) in the Parana State.

It is important to emphasize that this is the first serological detection of anti- $B$. ovis antibodies performed in sheep herds with genealogical records from the state of Parana, Brazil. In Parana State, studying commercial flocks, detection of $B$. ovis were recorded an incidence of $1.40 \%$ by Cunha Filho et al. (2007) in the north central mesoregion of Parana, and $18,26 \%$ by Oliveira et al. (2016) in the northwestern microregion of Parana.

Other states in southern Brazil reported higher occurrence of B. ovis antibodies in sheep flocks, with $18.84 \%$ of seropositive animals in Santa Catarina State (Schafer et al., 1997), 13.4\% State (Magalhães Neto and Gil-Turnes, 1996), and $2.89 \%$ (Machado et al., 2015) in Rio Grande do Sul, but both studies analyzed intensive half-bred herds, not purebred animals, maybe justifying the higher occurrence when compared to this study, as more intensive systems can contribute to the introduction and persistence of $B$. ovis infection in sheep flocks (Elderbrook et al., 2019) and rams from large flocks were 14 times more likely to become infected than rams from small flocks (Chávez et al., 2013). It is also important to stress that molecular characterization showed a high genetic diversity among $B$. ovis field isolates from Rio Grande do Sul State, Brazil (Dorneles et al., 2014), reinforcing the importance of studies on $B$. ovis survey.

The low occurrence observed in this study can be explained by the fact that purebred sheep with genealogical record are constantly undergoing clinical exams, health management and are kept in low demographic concentrations. According to Lone et al. (2013), the prevalence of brucellosis was higher in farms without zootechnical bookkeeping and sanitary controlling (14.14\%) than those who carry out the zootechnical and sanitary management of the herd $(3.23 \%)$, and this may be due to the good management practices of organized farms, such as the selection of healthy animals for reproduction, which could justify the result obtained in the present study.

Since less than $50 \%$ of rams infected with $B$. ovis develop a palpable epididymitis (Van Metre et al., 2012), the disease is introduced into a flock after the introduction of an infected ram, the most common route of disease spread is indirect ramto-ram transmission via passive venereal contact with ewes during the breeding season and transition also occurs directly from ram-to-ram via oral and mucosal routes outside the breeding season (Hartley et al., 1955; Buddle, 1955; Blasco, 2010), it is epidemiologically interesting to highlight that the only two seropositive animals were rams $(n=2 / 165)$ without epididymitis, reinforcing the subclinical character of the disease.

Data concerning B. ovis in Brazil are conflicting, which requires future clarifying studies. About this, in Sao Paulo State, infected sheep with $B$. ovis were not found in tests of AGID, indirect enzyme immunoassay (ELISA-I) and the complement fixation test (FC) (Marinho and Mathias, 1996; Chiebao, 2011), whereas Rizzo and collaborators demonstrated an incidence of $B$. ovis in sheep flocks from Sao Paulo State of $1.96 \%$ (2009) and $1.7 \%$ (2014), respectively, but studies demonstrated a frequent non-agreement of different serological test to detect $B$. ovis infection in sheep herds (Praud et al., 2012; Elderbrook et al., 2020).

Elderbrook et al. (2019) hypothesized that seroprevalence would be significantly higher after the breeding season compared to before the breeding season because $B$. ovis is sexually transmitted (Hartley et al., 1955; Buddle, 1955; Blasco, 2010). In contrast, the authors observed higher apparent seroprevalence before the breeding season than after the breeding season, similar to this study, carried out previously to the breeding season. Explanations for this finding include: 1) infection and transmission of B. ovis is occurring more often directly from ram-to-ram before the breeding season, 2) there is a lack of seroconversion in animals after $B$. ovis exposure (Elderbrook et al., 2019). To the best of our knowledge, no previous studies have considered 
time of sample collection relative to breeding season as a possible risk factor for seropositivity in Brazil, but a more comprehensive and controlled investigation into this may be useful in the future.

The positive animals belonged to a semi-confined farm with a history of abortion, acquisition of animals in the last two years and participations in fairs. After obtaining the positive result, the sheep breeder reported that had acquired animals from different herds and participated in fairs in the states of Parana, Rio Grande do Sul, and São Paulo. The breeder also reported that he had never tested the herd for $B$. ovis, even less had required testing for the acquisition of new animals, which could have contributed to the obtained seropositivity. Santos et al. (2013) observed that animal acquisition is a potential risk factor for disease incidence, since $27.6 \%$ of the properties that acquired animals showed seropositivity, in comparison to the $12.8 \%$ seropositivity observed in the properties that did not acquire animals.

The low antibody detection herein described may have occurred even if AGID is the standard test according to MAPA for B. ovis antibodies detection (Brazil, 2004), since ELISA has been more promising as diagnostic tool (Elderbrook et al., 2020), representing this study limitation, but it does not exclude the fact that serologically negative rams can excrete the organism whereas serologically positive rams may not excrete the organism (Elderbrook et al., 2020), demonstrating that the diagnosis of $\mathrm{B}$. ovis is still a challenge.

Concerning the inexistence of consistent epidemiological studies on risk factors, and the varying occurrence levels of $B$. ovis infection in the country, more studies are necessary around the infection profile, as well as also comparing different diagnostic tools, which should lead to improved management plans of sheep flocks worldwide.

\section{CONCLUSION}

It is concluded that ovine brucellosis is present in purebred sheep in the Parana State, Brazil, in a low occurrence under the conditions of the present study.

\section{REFERENCES}

ALVES, J.C. Detection of Brucella ovis in ovine from Paraíba State, in the northeast region of Brazil. Braz. J. Microbiol., v.41, p.365-367, 2010.

ARAUJO, B.R.; COSTA, J.N.; SOUZA, T.S. et al. Seroepidemiology of sheep brucellosis in the microregion of Feira de Santana, BA, Brazil. Braz. J. Vet. Anim. Sci., v.50, p.129-135, 2013.

AZEVEDO, S.S.; ALVES, C.J.; ALVES, F.A.L. et al. Ocorrência de anticorpos anti-Brucella ovis em ovinos procedentes de quatro municípios do Estado do Rio Grande do Norte, Brasil. Agropecu. Téc., v.25, p.45-50, 2014.

BLASCO, J.M. Brucella ovis infection. In:

(Ed.). Infectious and parasitic diseases of livestock. Paris: Tec \& Doc, 2010. p.354-367.

BRAZIL. Ministry of Agriculture, Livestock and Food Supply. 2004. Ordinance No. 102, December 17th, 2004. Provides for the National Plan for Surveillance and Control of Ovine Epididymitis Brucella ovis. Diário Oficial da União, Brasília, December 17th, 2004. Available in: http://www.agricultura.gov.br/legislacao Accessed in: 3 Mar. 2018.

BUDDLE, M.B. Observations on the transmission of Brucella infection in sheep. N.Z. Vet. J., v.3, p.10-19, 1955.

CARTAS climáticas do Paraná. Parana: IAPAR, 2017. Available in: http://www.iapar.br/ modules/conteudo/conteudo.php?conteudo $=863$

Accessed in: 3 Mar. 2019.

CHÁVEZ, J.M.C.; CHÁIREZ, F.G.E.; FLORES, C.F.A. et al. Possible risk factors for serological prevalence of Brucella ovis in Zacatecas, Mexico. Rev. Mex. Cienc. Pecu., v.4, p.61-74, 2013.

CHIEBAO, D.P. Epididimite ovina: análise da situação no município de Piedade, São Paulo. Pesqui. Tec., v.8, p.16, 2011.

COLETO, Z.F.; PINHEIRO JUNIOR, J.W.; MOTA, R.A. Ocorrência de infecção por Brucella ovis em ovinos do Estado de Pernambuco e sua participação em distúrbios reprodutivos nesta espécie (estudos preliminares). Rev. Bras. Reprod. Anim., v.27, p.551-553, 2003. 
CUNHA FILHO, L.F.C.; LEUZZI JUNIOR, L.A.; SILVA, L.C. et al. Ocorrência de ovinos reagentes à prova de imunodifusão em gel ágar, para Brucella ovis, em propriedades da região norte do Paraná. Rev. UNOPAR Cient. Cienc. Biol. Saúde, v.9, p.67-70, 2007.

DORNELES, E.M.; FREIRE, G.N.; DASSO, M.G. et al. Genetic diversity of Brucella ovis isolates from Rio Grande do Sul, Brazil, by MLVA16. BMC Res Notes, v.7, p.1-5, 2014.

EFETIVO do rebanho ovino. Rio de Janeiro: IBGE, 2019. Available in: https://sidra.ibge.gov.br/tabela/3939. Accessed in: 18 Mar. 2020.

ELDERBROOK, M.; SCHUMAKER, B.; CORNISH, T. et al. Seroprevalence and risk factors of Brucella ovis in domestic sheep in Wyoming, USA. BMC Vet. Res., v.15, p.246, 2019.

ELDERBROOK, M.J.; SCHUMAKER, B.A.; UETI, M.W. et al. Comparison of 2 ELISAs for detecting exposure to Brucella ovis. J. Vet. Diagn. Invest., v.32, p.700-705, 2020.

ERDENEBAATAR, J.; BAYARSAIKHAN, B.; YONDONDORJ, A. et al. Epidemiological and serological survey of brucellosis in Mongoliaby ELISA using sarcosine extracts. Microbiol. Immunol., v.48, p.571-577, 2004.

ESTEIN, S.M.; FIORENTINO, M.A.; PAOLICCHI, F.A. et al. The polymeric antigen BLSOmp31 confers protection against Brucella ovis infection in rams. Vaccne, v.27, p.6704-6711, 2009.

FARIAS, A.E.; HIGINO, S.S.S.; AZEVEDO, S.S. et al. Epidemiological evaluation of reproductive infectious agents in sheep in the Brazilian Semiarid. World J. Vet. Sci., v.1, p.1317, 2013.

HARTLEY, W.J.; JEBSON, J.L.; MCFARLANE, D. Some observations on natural transmission of ovine brucellosis. N.Z. Vet. J., v.3, p.5-10, 1955.

LIMA, A.M.C.; ALVES, F.S.F.; ALVES, S.M.A. et al. Epidemiological characterization and risk factors associated with Brucella ovis infection in sheep from the states of Rio Grande do Norte, Paraíba, and Sergipe. Semin. Cienc. Agrar., v.41, p.531-544, 2020.
LONE, I.M.; BABA, A.; SHAH, M. et al. Seroprevalence of brucellosis in sheep of organized and unorganized sector of Kashmirvalley. Vet. World, v.6, p.530-533, 2013.

MACHADO, G.; SANTOS, D.V.; KOHEK, I. et al. Seroprevalence of Brucella ovis in rams and associated flock level risk factors in the state of Rio Grande do Sul, Brazil. Prev. Vet. Med., v.121, p.183-187, 2015.

MAGALHÃES-NETO, A.; GIL-TURNES, C. Brucelose ovina no Rio Grande do Sul. Pesqui. Vet. Bras., v.16, p.75-79, 1996.

MANHEZZO, T.G.; CONCEIÇÃO, L.A.V.; CASTRO, B.G. Ocorrência de anticorpos antiBrucella ovis em ovinos de Sinop e região, Mato Grosso, Brasil. Rev. Patol. Trop., v.4, p.483-388, 2015.

MARINHO, M.; MATHIAS, L.A. Pesquisa de anticorpos contra Brucella ovis em ovinos do estado de São Paulo. Pesqu. Vet. Bras., v.16, p.4548, 1996.

MARTINS N.E.X.; ALMEIDA J.D.M.; SILVA M.G. et al. Prevalência de anticorpos antiBrucella ovis e anti-Brucella abortus em ovinos do município de Colinas, Tocantins, Brasil. Vet. Patol. Trop., v.42, p.147-160, 2013.

OLIVEIRA, L.A.; ZANIOLO, M.M.; DIAS, E.H. Leptospirosis and brucellosis seroepidemiology in sheep and dogs from non-mechanized rural properties in the northwestern region in the state of Paraná. Semin. Cienc. Agrar., v. 37, p. $3147-$ 3158, 2016.

OVINE epididymitis (Brucella ovis). OIE terrestrial manual. World Organization for Animal Health. 2015. p.1-13. Available in: http://www.oie.int/fileadmin/Home/eng/Health_s tandards/tahm/3.07.07_OVINE_EPI. Accessed in: 18 Mar. 2020.

PARANÁ. State Secretariat for Agriculture and Supply. Provides for data on livestock in Paraná. Paraná State Government. Department of Rural Economy, 2017. Avaiable in: www.agricultura.gov.br. Accessed in: 18 Mar. 2020.

PINHEIRO JUNIOR, J.W.; OLIVEIRA, A.A.F.; MOTA, R.A. Ocorrência de ovinos sororeatores para Brucella ovis no Estado de Alagoas. Vet. Zootec., v.16, p.500-508, 2009. 
POESTER, F.P.; SAMARTINO, L.E.; SANTOS, R.L. Pathogenesis and pathobiology of brucellosis in livestock. Rev. Sci. Tech.,v. 32, p. 105-115, 2013.

PRAUD, A.; CHAMPION, J.L.; CORDE, Y. et al. Assessment of the diagnostic sensitivity and specificity of an indirect ELISA kit for the diagnosis of Brucella ovis infection in rams. BMC Vet. Res., v.9, p.68, 2012.

RIZZO, H.; GREGORY, L.; BERALDI, F. et al. Ocorrência de anticorpos anti-Brucella ovis em ovinos com histórico de distúrbios reprodutivos no estado de São Paulo, Brasil. Arq. Inst. Biol., v.81, p.99-106, 2014.

RIZZO, H.; GREGORY, L.; PINHEIRO, E.S. Incidência de Brucella ovis em ovinos com histórico de distúrbios reprodutivos no estado de São Paulo, Brasil. Cienc. Anim. Bras., v.1, p.3035, 2009.

SANTOS, F.A.; HIGINO, S.S.S.; AZEVEDO, S.S. et al. Caracterização epidemiológica e fatores de risco associados à infecção por Brucella ovis em ovinos deslanados do semiárido paraibano. Pesqu. Vet. Bras., v.33, p.459-463, 2013.

SHÄFER, I.; VAZ, A.; RAMELLA, J.; COUTINHO, G. Prevalência de carneiros reagentes à prova de imunodifusão em gel para Brucella ovis no Município de Lages, SC. Hora Vet., v.17, p.60-61, 1997.
SILVA, J.B.A.; FEIJÓ, F.M.C.; TEIXEIRA, M.F.S. et al. Frequência de brucelose ovina causada por Brucella ovis em rebanhos do estado do Rio Grande do Norte, Brasil. Cienc. Anim., v.13, p.51-54, 2003.

SILVA, N.S.; BARROS, I.N.; DASSO, M.G. et al. Detecção de anticorpos anti-Brucella ovis em ovinos do estado da Bahia. Rev. Bras. Saúde Prod. Anim., v.10, p.852-859, 2009.

SOUZA, T.S.; COSTA, J.N.; MARTINEZ, P.M. et al. Inquérito soro-epidemiológico de Brucella ovis em rebanhos ovinos no semiárido baiano. Arq. Inst. Biol., v.79, p.277-281, 2012.

TEIXEIRA, L.S.A.; PINHO, F.A.; BATISTA, J.F. et al. Risk factors and detection of brucella ovis in naturally infected rams and ewes. Rev. Bras. Cienc. Vet., v.28, p.48-52, 2021.

VAN METRE, D.C.; RAO, S.; KIMBERLING, C.V. Factors associated with failure in breeding soundness examination of Western USA rams. Prev. Vet. Med., v.105, p.118-126, 2012.

XAVIER, M.N.; SANT'ANNA, F.M.; SILVA, T.M.A. A comparison of two agar gel immunodiffusion methods and a complement fixation test for serologic diagnosis of Brucella ovis infection in experimentally infected rams. Arq. Bras. Med. Vet. Zootec., v.63, p.1016-1021, 2011. 